\title{
Risk, competition, efficiency and its interrelationships: evidence from the Chinese banking industry
}

\begin{abstract}
Purpose - This study investigates the interrelationships between efficiency, competition and risk in the Chinese banking industry.

Design/methodology/approach - parametric stochastic frontier analysis is used to estimate bank efficiency; Lerner index is used as the competition indicator; accounting ratios and a translog function are used to measure different types of risk; and finally the three-stage least square estimator is used to investigate the interrelationships.

Findings - The results of this study show that the impact of competition on different types of risk is significant and positive, while there is a significant and positive impact of credit risk, liquidity risk and capital risk on bank competition. In addition, the findings demonstrate that the interrelationships between efficiency and competition is significant and negative. We do not find any robust interrelationships between different types of risk and different types of efficiency; we find that diversification and higher levels of profitability reduce bank credit risk. The results suggest that a higher developed banking sector reduces the level of bank competition in China.
\end{abstract}

Practical implication - concrete policies are provided to bank managers and the banking regulatory authority in China.

Originality/value - This is the first piece of research that comprehensively investigates the interrelationships between different types of risk, competition and different efficiencies in China.

Keywords: risk, competition, efficiency, Chinese banking, 3SLS 


\section{Introduction}

China's economic development has attracted great attention from the rest of the world. During the period 2003-2017, China had an annual GDP growth rate of over 9.4\%. From 1978 onwards, the Chinese banking sector underwent sustainable and healthy development through several rounds of banking reforms initiated by the government. The main purpose of these banking reforms was to increase competitive conditions, enhance stability and improve the performance of the Chinese banking sector. However, according to statistics from the China Banking Regulatory Commission (CBRC), the assets share of state-owned commercial banks (SOCBs) in total banking sector assets decreased between 2003 and 2017 to a low point of $36.77 \%$. On the other hand, the city commercial banks (CCBs) kept increasing in size and in 2017 they held $12.57 \%$ of total banking sector assets. Although the amount of assets held by the joint-stock commercial banks (JSCBs) experienced slight volatility over the period, they ended up with $17.81 \%$ share at the end of 2017 . This shows that competitive conditions in the Chinese banking sector have increased significantly, although the stateowned commercial banks still dominate the banking industry. Although there are numerous studies investigating the competitive conditions, there is still a question that needs to be answered: what is the impact of competition on bank efficiency from the profit, cost and revenue perspectives, while simultaneously controlling for its impact on bank risk? Answering this question would be of particular importance to the banking regulatory authority in order to make relevant policies.

There have been few pieces of research investigating competitive conditions in the Chinese banking sector (Yuan, 2006; Fu, 2009; Masood and Sergi, 2011; Park, 2013; Tan and Floros, 2013a; Tan, 2014), while the above statistics give a general picture of risk conditions in the Chinese banking industry, and more specifically Tan (2017), Tan (2018) as well as Tan and Floros (2018) investigate different types of risk for different ownerships of Chinese commercial banks. There have been a number of studies examining the effect of competition on risk-taking behaviour in banking industry (Liu et al., 2012; Beck et al., 2013a; Liu and Wilson, 2013; Liu et al., 2013; Soedarmono et al., 2013; Agoraki et al., 2014; Anginer et al., 2014; Fu et al, 2014; Schaeck and Cihak, 2014), however, there have been very few studies examining the impact of competition on risk-taking behaviour in the Chinese banking industry (Tan and Floros, 2013b; Tan, 2014; Tan and Floros, 2014).

In Summary, the previous banking studies on the competition-risk relationship had a few common characteristics: 1) in terms of the competition measurement, all the studies measured the level of bank competition by one of the indicators including Lerner index, bank concentration ratio and Boone indicator; 2) related to the measurement of bank risk, the empirical studies mainly focused on credit risk, insolvency or volatility of returns. 
The current literature only examines the potential two-way relationships between competition and different types of risk (credit risk, capital risk, liquidity risk and insolvency risk); our study contributes to banking literature regarding the relationships between competition and risk by simultaneously investigating the impact of bank competition on bank efficiency from the profit, cost and revenue perspectives.

There have been a number of empirical studies examining the performance of Chinese commercial banks (Garcia-Herrero et al., 2009; Liang et al., 2013; Sun et al., 2013; Tan and Floros, 2013a; Tan, 2014). In particular, Tan and Floros (2013a) tested the interrelationships between risk, capital and efficiency in the Chinese banking industry, and most recently Tan and Floros (2018) tested the interrelationships between risk, efficiency and competition in the Chinese banking industry. The efficiency was measured by nonparametric Data Envelopment Analysis (DEA), and four different types of risk are considered, including credit risk, liquidity risk, capital risk and insolvency risk. The competitive condition in the Chinese banking industry was measured by Lerner index.

We differentiate ourselves from Tan and Floros (2013a) as well as Tan and Floros (2018) by using the parametric stochastic frontier analysis to measure bank efficiency. Fries and Taci (2015) argue that compared to the non-parametric DEA, the stochastic frontier analysis will generate more accurate results for efficiency analysis in developing economies in which there are problems of measurement error and uncertain economic environments. We further provide more useful information compared to the previous studies by investigating profit efficiency rather than technical, pure technical and scale efficiencies, with the former focusing on generating profits in a more efficient way, which is the aim of banking operations, whereas the estimation of technical, pure technical and scale efficiencies by Tan and Floros (2013a) and Tan and Floros (2018) focused more on generating the volumes of business in a more efficient way ${ }^{1}$.

In summary, our contributions do not only lie to the fact that we use a different efficiency estimation technique to get more reliable results of different types of efficiencies (cost, revenue and profit), but also the attempt to evaluate the potential interrelationships among these different types of efficiencies, bank competition and different types of risk makes a significant contribution to the banking literature in general.

The interrelationships between risk, competition and efficiency are examined under the Granger causality test. The current paper fills the gaps of empirical literature and particularly extends the study of Tan and Floros (2018) in the following ways: 1) parametric Stochastic Frontier analysis is used to measure the efficiency of

\footnotetext{
${ }^{1}$ Profit efficiency does not only require technical efficiency and both input and output allocative efficiency, it also requires the efficiencies to be achieved at a proper scale (Fitzpatrick and McQuinn, 2008). In addition, profit efficiency takes better consideration of cost inefficiency because the deviation of cost inefficiency from the optimal point is embodied in profit efficiency (Berger and Mester, 1997).
} 
Chinese commercial banks; 2) instead of technical efficiency, pure technical efficiency and scale efficiencies, the current study investigates cost, profit and revenue efficiencies, which is supposed to provide more practical implications to the Chinese commercial banks; 3) three-stage least square estimator rather than Granger causality test is used to examine the interrelationships between risk, efficiency and competition in the Chinese banking industry.

The results of this study show that the impact of competition on different types of risk is significant and positive, while there is a significant and positive impact of credit risk, liquidity risk and capital risk on bank competition. In addition, the findings demonstrate that the interrelationships between efficiency and competition are significant and negative. We do not find any robust interrelationships between different types of risk and different types of efficiency. We find that diversification and higher levels of profitability reduce bank credit risk. The results suggest that a higher developed banking sector reduces the level of bank competition in China.

The results of the current paper provide a number of policy implications to bank managers in China. as well as the banking regulatory authority. From the bank managers' perspective, we recommend that 1) They should further improve the process of credit checking, monitoring and management to reduce the level of credit risk; 2) When engaging in allocating credits to the economic sector, Chinese bank managers should focus more on allocating short-term loans, the resulted reduction in the level of liquidity risk will improve bank performance; 3) Bank managers should keep a higher level of capital, which is also for the purpose of risk reduction and performance improvement. From the banking regulator's perspective, it is recommended that: 1) Relevant rules and regulations should be established to forbid banks from engaging in risky activities, and restrict them from lending to specific borrowers with high levels of risk; 2) The bank regulator should set up high but reasonable capital and liquidity requirements in order to reduce capital and liquidity risk in the banking system; 3) A relevant reward system should be established to attract talent people in the banking industry, and also encourage research and innovative activities; the resulted exploration of new business areas will diversify banking activities, improve the development of the banking sector in China, and improve bank stability.

This paper has the following structure: Section 2 reviews the relevant literature on the interrelationships between risk, competition and efficiency in the banking sector; Section 3 presents the methodology, while Section 4 presents the data and discusses relevant results; Section 5 briefly discusses the robustness check; and finally, Section 6 concludes the paper. 


\section{Literature review and hypotheses development}

\subsection{The impacts of competition and efficiency on risk in the banking industry}

Competition-fragility hypothesis argues that banks have the ability to withstand shocks and to decrease risktaking behaviour due to the fact that in a less competitive environment, banks are able to earn higher profitability through monopoly rents (Allen and Gale, 2004; Boyd and De Nicole, 2005). The competitionstability view suggests that in a less competitive banking market, banks charge higher interest rates, which increases the probability of defaulting on loan repayments. By allowing for imperfect correlation across individual firms' default probabilities, Martinez-Miera and Repullo (2010) suggested that there is a U-shape relationship between competition and risk; therefore, as the number of banks increases, the probability of bank default first declines but then increases. Overall, there is still no consensus with regard to the issue of whether competition precedes bank stability or fragility. In terms of the Chinese banking industry, the studies of Tan and Anchor (2017a) and Tan and Floros (2018) share a common finding that higher levels of competition reduce insolvency risk and increase liquidity risk.

The bad management hypothesis (Berger and DeYoung, 1997) suggests that lower levels of efficiency leads to higher costs because banks do not monitor credit adequately, and also they do not control expenses efficiently. The declines in efficiency will result in increases in banks' risk because of credit, operational, market and reputational problems. On the other hand, the moral hazard hypothesis (Jeitschko and Jeung, 2005) argues that banks with lower levels of efficiency tend to take higher risks. The moral hazard problem arising from the presence of informational friction and the existence of agency problems makes bank managers take on higher risk. In terms of the Chinese banking studies, both Tan and Floros (2013) and Tan and Floros (2018) find that higher efficiency leads to higher credit risk and higher insolvency risk. Through reviewing the literature, we have formed the following hypotheses:

Hypothesis 1: Higher levels of bank competition increase the level of insolvency risk and liquidity risk. Hypothesis 2: Higher levels of efficiency increase the level of credit risk and insolvency risk.

\subsection{The impacts of risk and efficiency on competition in the banking industry}

The main argument with regard to the impact of risk on market power suggests that banks with higher ability to manage risk conditions will increase the profit-cost margin and further increase market power (Fernandez de Guevara and Maudos, 2007). The impact of efficiency on competition is mainly documented in the efficient-structure hypothesis (Demsetz, 1973). The hypothesis argues that performance plays a decisive role 
in the structure. To be more specific, this theory suggests that banks with higher levels of efficiency gain market share at the expenses of less efficient banks, so the concentration increases and the competitive conditions reduce. In terms of the Chinese banking industry, Tan and Floros (2018) found that higher ability to manage liquidity risk decreases bank competition (increase bank market power), and there is no clear evidence regarding the impact of efficiency on competition. Therefore, based on the review of the relevant literature, we have formed the following hypotheses:

Hypothesis 3: There is a significant and positive impact of liquidity risk on bank competition.

Hypothesis 4: There is no significant impact of efficiency on bank competition.

\subsection{The impacts of competition and risk on efficiency in the banking industry}

The competition-inefficiency hypothesis suggests that competition leads to a decline in bank efficiency for the following reasons. First, Boot and Schmeits (2005) argued that the relationships between customers and banks are less stable and shorter in a more highly competitive environment. Furthermore, higher bank competition increases customers' propensities to switch to other service providers. This phenomenon will amplify the information asymmetries and requires additional resources for screening and monitoring borrowers. Second, Chan et al. (1986) argued that in a competitive environment there is a shorter duration of bank relationships; the reduction of relationship-building activities inhibits the reusability and value of information. The competition-efficiency hypothesis (Zarutskie, 2013) argues that higher competition induces banks to specialize and focus on certain types of loans or particular groups of borrowers. It also induces bank managers to adjust their lending technologies. The banks are able to lower the costs of processing and originating loans and better monitor the borrowers. This positive impact is in line with the "Quiet Life hypothesis", which argues that managers with monopoly power enjoy a share of monopoly rents, and therefore they are careless in expense management which leads to a decline in efficiency. The bad luck hypothesis (Berger and DeYoung, 1997) argues risk has a significant impact on efficiency. The hypothesis suggests that an increase in problem loans for the banks is mainly attributed to external events rather than the manager's skills or their risk-taking appetite. The increase in risk incurs additional costs and managerial efforts. Thus, increase in risk precedes a decline in bank efficiency. In terms of the Chinese banking industry, Tan and Anchor (2017b) found that higher levels of liquidity risk reduces efficiency and the level of efficiency is lower under a stronger competitive banking environment. Based on the literature review, we have formed the following hypotheses:

Hypothesis 5: There is a significant and negative impact of liquidity risk on bank efficiency. Hypothesis 6: There is a significant and negative impact of competition on bank efficiency. 


\subsection{The interrelationships between risk, competition and efficiency in the banking industry}

In the empirical literature, there were very few studies that tested the interrelationships between risk, competition and efficiency in the banking sector. Using a sample of investment banks in ten large, developed countries over the period 2000-2008, Fiordelisi et al. (2011b) examined these inter-relationships under Generalized Method of Moments estimators. The findings show that the competition in investment banking worldwide is quite limited, and although relatively low competitive pressures are helpful in enhancing banks' stability, the results report that banks tend to undertake higher risks in a lower competitive environment. Their findings show that competition-stability paradigm holds for the investment banking industry.

Using a sample of 272 commercial banks from 15 Latin American countries for the period 2001-2008, Kasman and Carrallo (2014) tested the interrelationships between competition, risk and efficiency under a Granger causality technique. The results show that higher competition leads to greater financial stability, while banks with higher stability enjoy greater market power; banks with greater market power also have higher efficiency.

\section{Methodology}

\subsection{Model specification}

The current study specifies a system of equations, and the estimation of these equations is under a threestage least square estimator to deal with the endogeneity issue. The system of equations has the following form:

$$
\begin{aligned}
& \text { Risk }_{i t}=\alpha_{0}+\alpha_{1} \text { efficiency }_{i t}+\alpha_{2} \text { competition }_{i t}+\alpha_{3} \text { diverse }_{i t}+\alpha_{4} \text { profits }_{i t}+\mu_{1} \\
& \text { efficiency }_{i t}=\delta_{0}+\delta_{1} \text { competition }_{i t}+\delta_{2} \text { ris }_{i t}+\delta_{3} \text { size }_{i t}+\delta_{4} \text { inflation }_{t}+\mu_{2} \\
& \text { competition }_{i t}=\gamma_{0}+\gamma_{1} \text { risk }_{i t}+\gamma_{2} \text { efficiency }_{i t}+\gamma_{3} B S D_{t}+\gamma_{4} \text { SMD }_{t}+\gamma_{5} G D P G_{t}+\mu_{3}
\end{aligned}
$$

Where subscript $i$ and $j$ represent a specific bank operating in a specific year, the risk is different risk conditions in the Chinese banking industry, including credit risk, liquidity risk, capital risk, as well as insolvency risk. Efficiency is the cost, profit and revenue efficiency scores derived from the stochastic frontier approach, while competition is the competition indicator (the Lerner index). The simultaneous equations also control for various bank-specific, industry-specific and macroeconomic variables. In order to use the threestage least square estimator in the analysis, a set of unique variables are needed for a specific equation but not the other two. These instruments are supposed to be exogenous and do not correlate with the error term. We expect that the following variables only affect specific dependent variables, therefore they only appear in one specific equation but not the other two. 


\section{Equation 1 only}

Bank diversification is used in the risk equation, which is represented by diverse. It is measured by the ratio of non-interest income to gross revenue. We expect that higher degrees of diversification will reduce bank risk due to the fact that engaging in a variety of businesses will reduce the degree of reliance on a specific business activity; in particular, during economic recession, the loan business will be significantly affected in a negative way. Strongly focusing only on the loan business will significantly increase the volumes of nonperforming loans, and therefore the banks have higher levels of risk. Profitability is another unique variable in the risk equation; it is measured by the return on assets. It can be argued that banks with higher levels of profitability will have a higher ability to absorb negative shocks. An example is when banks accumulate a large number of non-performing loans, as banks with higher levels of profitability would be able to absorb the negative shocks and unexpected losses, and therefore further reduce the level of risk compared to the banks with lower levels of profitability (Konara et al., 2019).

\section{Equation 2 only}

Bank size is used in the efficiency equation. It is measured by the natural logarithm of total assets. We include this variable in the efficiency equation due to the consideration that large banks are supposed to have a higher level of efficiency derived from economies of scale and economies of scope.

Inflation is the second unique variable that is used in the efficiency equation. It is measured by the percentage change in the consumer price index. Kaman and Yildirim (2006) argue that bank behaviour would be affected by higher levels of inflation, and higher levels of inflation increase bank competition which further reduces the level of bank efficiency.

\section{Equation 3 only}

Banking sector development is the first unique variable in the competition equation, represented by $B S D$; this variable is measured by the ratio of total banking sector assets to GDP. Tan and Floros (2012) argue that a more highly developed banking sector indicates that there is a higher level of demand for banking products and services, and higher demand over supply will increase the price level for banking services. This indicates that there is a lower level of competition; this is due to the fact that with higher levels of banking competition, banks normally reduce the price levels of their services to sustain their competitive advantage.

Stock market development is the second unique variable in the competition equation, represented by $S M D$; this variable is measured by the ratio of market capitalization of listed companies to GDP. Tan (2016) argues that a higher level of development in the stock market increases the number of companies that obtain funds from the stock market rather than from the banks, and this will reduce the volumes of bank businesses. In order to get loan business, banks would take different strategies (e.g. price cuts) to compete with their counterparts. 
Finally, GDP growth is the last unique variable in the competition equation, represented by GDPG; this variable is measured by the annual rate of GDP growth. During periods of economic boom, governments encourage different types of investment through using loose monetary policy, and the resulting reduction in the level of interest rate reduces companies' borrowing costs and further increases the demand on banking businesses. This would have a similar effect as the one on banking sector development we discussed previously - higher levels of demand on banking services over supply leads to a lower level of bank competition.

We conducted the over-identification test and the test statistics show that the instruments used are valid.

\subsection{Variable construction}

\subsubsection{Estimation on different types of risk in the Chinese banking industry}

This paper investigates different types of risk-taking behaviour in the Chinese banking industry, including credit risk, liquidity risk, capital risk and insolvency risk, and the current paper uses relevant accounting ratios to measure these four types of risk. To be more specific, the ratio of non-performing loans to total loans measures the credit risk, and the higher figure of this ratio indicates higher credit risk (Fiordelisi et al., 2011a; Abedifar et al., 2013; Beck et al., 2013b; Liang et al., 2013); the ratio of liquid assets to total assets measures the liquidity risk, and the higher figure of this ratio shows that the bank has lower liquidity risk (Altunbas et al., 2000; Altunbas et al., 2007; Goddard et al., 2009); the total regulatory capital ratio measures the capital risk, and the higher total regulatory capital ratio indicates that the bank has lower capital risk (Molyneux et al., 2014); and the last type of risk-taking behaviour is insolvency risk, and rather than using the accounting ratio, namely the Z-score, the current study uses a translog specification to estimate the stability inefficiency (Tan, 2018), which reportedly provides more robust results².

\subsubsection{Estimation of competition in the Chinese banking sector - Lerner index}

The Lerner index is defined as the difference between a bank's price and the marginal cost, divided by the price. The index value ranges from a maximum of 1 to a minimum of 0 , with higher numbers indicating greater market power and hence less competition. The Lerner index represents the extent to which a particular bank has the market power to set its price above the marginal cost.

The average price of bank production (proxied by total assets) as the ratio of total revenue to total assets measures the price; this measurement follows the studies of Fernandez de Guevara et al. (2005) and CarboValverde et al. (2009). A translog cost function with three outputs and two input prices measures the marginal

\footnotetext{
${ }^{2}$ For detailed procedure to estimate stability inefficiency, please see Tan (2018).
} 
cost. The cost function has the following form:

$$
L N\left(\frac{C}{W_{2}}\right)_{i t}=\delta_{0}+\sum_{j} \delta_{j} L N Y_{j i t}+\frac{1}{2} \sum_{j} \sum_{k} \delta_{j k} L N Y_{j i t} L N Y_{k i t}+\beta_{1} L N\left(\frac{W_{1}}{W_{2}}\right)_{i t}+\frac{1}{2} \beta_{11} L N\left(\frac{W_{1}}{W_{2}}\right)_{i t} L N\left(\frac{W_{1}}{W_{2}}\right)_{i t}+\sum_{j} \theta_{j} L N Y_{j i t} L N\left(\frac{W_{1}}{W_{2}}\right)_{i t}+\varepsilon_{i t}
$$

$\mathrm{C}$ represents the total cost of the bank; Y represents four outputs including total deposits, total loans, noninterest income and other earning assets; and $\mathrm{W}$ stands for two input prices, with $\mathrm{W} 1$ representing the price of funds which is measured by the ratio of interest expenses to total deposits, and W2 representing the price of capital, which is measured by the ratio of non-interest expenses to fixed assets. Two input prices are considered due to the fact that non-interest expenses include the labour cost as well (Hasan and Morton, 2003). In other words, the price of capital considers the factors relating to the price of physical capital as well as the price of human capital. The linear homogeneity is ensured by normalizing the dependent variable and W1 by anther input price W2.

The marginal cost of loans can be obtained by taking the first derivative of the dependent variable in the above equation in relationship to the output loans as follows:

$$
M C_{i l t}=\left(\frac{C_{i t} / W_{2}}{Y_{i l t}}\right)\left(\delta_{j=l}+2 \delta_{l l} L N Y_{i l t}+\sum_{k-1 \ldots k, k \neq l} \delta_{l k} L N Y_{i k t}+\theta_{l} L N\left(\frac{W_{1}}{W_{2}}\right)\right)
$$

Table 1 summarizes the variables used to measure the Lerner index

<<Table 1---about here>>

\subsubsection{Estimation of different types of efficiencies in the Chinese banking industry}

There are two main approaches which are widely used in estimating bank efficiency: they are Stochastic Frontier Approach (SFA) and Data Envelopment Analysis (DEA). The main argument for using DEA rather than parametric techniques, such as SFA, lies in the fact that it works particularly well with small samples. Furthermore, it is able to handle multiple inputs and outputs stated in different measurement units, and it does not necessitate knowledge of any functional form of the frontier (Charnes et al., 1995). Most empirical papers showed that using DEA to estimate the efficient frontier can yield robust results (Seiford and Thrall, 1990). However, although DEA has a few advantages with regard to efficiency estimation compared to SFA, it also suffers from a number of disadvantages.

First and foremost, DEA does not assume statistical noise, which means that the error term in the estimation is attributed to inefficiency. Therefore, the influence of a number of factors such as bad data, luck and extreme observations is accounted for as inefficiency in DEA. Secondly, Sun and Chang (2011) further argued that 
measuring DEA in small samples is sensitive to the difference between the number of firms and the sum of inputs and outputs used. Fries and Taci (2005) argued that the SFA is more appropriate over DEA in efficiency studies in developing countries where problems of measurement errors and uncertain economic environments are more likely to prevail. Therefore, the current study uses SFA to estimate cost efficiency in the Chinese banking industry. The efficiency level can be estimated by specifying the commonly used translog functional form for the cost function; the cost function will be the same as equation (4), while an additional equation has been added to separate the error term into two components as follows:

$\varepsilon_{i t}=\mu_{i t}+v_{i t}$

Here $v_{i t}$ is a two-sided normal disturbance term with zero mean and variance $\sigma_{v}^{2}$ and represents the effect of statistical noise, and $u_{i t}$ is a non-negative random disturbance term capturing the effects of inefficiency. With regard to the estimation of profit efficiency and revenue efficiency, we use the same specification and simply replace the dependent variable with profit and gross revenue. The profit indicator used is Return on Assets (ROA). Table 2 shows the summary statistics of the variables used to measure the efficiency of Chinese commercial banks.

$<<$ Table 2---about here >>

\subsection{Data and sampling}

The banking data includes 38 Chinese commercial banks (5 SOCBs, 12 JSCBs and 21 CCBs) over the period 2003-2017. With regard to the data sources, the current study collected the data of bank-specific variables from Bankscope and the annual financial statements of the banks, and the industry-specific variables and macroeconomic variables were from the $\mathrm{CBRC}$ annual reports as well as the World Bank database. Table 3 shows the summary statistics of the variables used in the current study.

The results show that the differences in liquidity risk undertaken by Chinese commercial banks are smaller than those of credit risk and capital risk. The higher levels of credit risk undertaken by Chinese commercial banks is attributed to the fact that, during 2003-2006, there were large volumes of non-performing loans in SOCBs, especially in the Agricultural Bank of China, while the large difference of capital risk is attributed to the 2006 opening of one joint-stock commercial bank, the China Bohai Bank, which has a total regulatory capital ratio of over $60 \%$. With regard to other bank-specific variables, the results indicate that Chinese banks have a big difference in the degree of diversified activities they engage in, while the difference in profitability amongst Chinese banks is relatively smaller. The difference in bank size is attributed to the fact that SOCBs are bigger than JSCBs, while CCBs are the smallest. The results further show that there is a stronger volatility with regard to stock market development than banking sector development and the macroeconomic 
environment. The stronger volatility of stock market development can mainly be attributed to the segregation reform initiated by the Chinese government in 2005 which led to a substantial amount of companies being listed on the stock exchange. By the end of 2007, there were 1,550 companies listed on the Shanghai and Hong Kong stock exchanges, the value of which amounted to RMB 32.71 billion, accounting for $132.6 \%$ of GDP in that year. On the other hand, the stock market development was in its early stages before 2005.

$<<$ Table 3--about here >>

\section{Empirical results}

\subsection{Competitive conditions in the Chinese banking industry}

Figure 1 shows the competitive conditions of the Chinese banking industry over the period examined. They are presented for all three different ownership types. It can be observed that the minimum value of the Lerner index is 0.38 , while the highest value is nearly 0.6 . A comparison of these values with Lerner index values from other countries demonstrates that Chinese commercial banks had substantially higher market power. To be more specific, research undertaken by Carbo et al. (2009) shows that the values of the Lerner index for the European Union banking sector ranged from 11-22\%, while for developed countries the average value of the Lerner index for the banking sectors was 22\% (Berger et al., 2009a). Fungacova et al. (2010) shows that the value of the Lerner index for the Russian banking sector was $21.4 \%$. These comparisons show that competition in the Chinese banking industry was very low.

The Lerner index suggests that between 2003 and 2017, city commercial banks had the highest market power compared to joint-stock commercial banks and state-owned commercial banks in general. In other words, the level of competition among city commercial banks was the lowest. The lower level of competition within CCBs can be explained as follows: 1) Most of the SOCBs and JSCBs had listed already on the stock exchange, but most of the CCBs had not made their initial public offering yet, which lowers pressure to obtain funds from the general public, further reducing competition among them; 2) One of the characteristics of this banking ownership type is that most of the CCBs still operated within the city where they were established (although the geographical limitation for operation had already been removed for CCBs, which had better performance).

In other words, each CCB just served the enterprises within their own city; this leads to a decline in bank competition.

$<<$ Figure 1---about here>> 


\subsection{Efficiency in the Chinese banking industry}

Figure 2 reports the results with regard to the cost, revenue and profit efficiencies of three different ownership types of Chinese commercial banks over the examined period. From this figure it can be seen that city commercial banks had the highest cost efficiency, while the state-owned commercial banks had the highest level of profit efficiency and revenue efficiency. Figure 3 shows the results with regard to cost, revenue and profit efficiencies of three different ownership types of Chinese commercial banks on an annual basis. The findings show that the cost efficiency of Chinese commercial banks was more stable over the examined period compared to profit efficiency, while Chinese commercial banks had the strongest volatility in revenue efficiency.

$<<$ Figure 2---about here $>>$

$<<$ Figure 3---about here $>>$

\subsection{The interrelationships between risk, competition and efficiency in the Chinese banking industry}

Table 4-7 presents the results with regard to the interrelationships between risk, competition and efficiency in the Chinese banking industry. The findings show that higher competition in the Chinese banking industry leads to high credit risk undertaken by Chinese commercial banks. This finding is in line with the competition-instability hypothesis. It was also found that the Chinese commercial banks with higher levels of credit risk have higher cost efficiency. This is not in line with the bad luck hypothesis. With regard to the impacts of efficiencies on credit risk, the findings show that the Chinese commercial banks with higher levels of efficiencies (cost efficiency, profit efficiency and revenue efficiency) have higher credit risk. The findings further report that higher credit risk undertaken by Chinese commercial banks increases competitive conditions in the Chinese banking industry. This is different from the finding of Fernandez de Guevara and Maudos (2007). This result is attributed to the fact that higher credit risk undertaken by Chinese commercial banks significantly increases the cost, while the resulted decrease in the price-cost margin leads to lower market power and higher competition.

We further find that higher efficiency reduces competitive conditions. This is not in line with hypothesis 4 and is different from the findings of Tan and Floros (2018). This can mainly be attributed to the fact that the current study examines cost, profit and revenue efficiencies, while Tan and Floros (2018) examine technical, pure technical and scale efficiencies. Different efficiencies reflect different aspects of banking operation; this therefore explains the different findings reported in this paper. Finally, it demonstrates that higher competition leads to lower efficiency of Chinese banks. 
The results indicate that higher levels of competition in the Chinese banking industry lead to higher levels of liquidity risk for Chinese commercial banks, which is in accordance with hypothesis 1 . It can be suggested that the Chinese commercial banks with higher levels of efficiencies have lower liquidity risk. The results show that higher levels of liquidity risk lead to a higher level of competition in the Chinese banking industry; this result accords with hypothesis 3. The findings further suggest that higher levels of efficiency of Chinese commercial banks result in a lower level of competition; this is in contrast with hypothesis 4 , but in line with the efficient-structure hypothesis.

These results indicate that higher levels of efficiency from the cost, profit and revenue perspectives will actually increase bank market power, however, this is not the case if we look at the efficiency from the perspective of volumes of production as reflected by technical, pure technical and scale efficiencies. We find that Chinese banks have lower efficiency in a more competitive banking environment; this is in line with hypothesis 6. Finally, we find that there is a significant and negative impact of liquidity risk on efficiencies. In other words, lower levels of liquidity risk lead to higher cost, revenue and profit efficiencies; this is exactly the same as the proposed hypothesis 5 .

The results report that higher levels of capital risk precede an increase in the level of competition, while higher levels of bank competition increase the level of capital risk. Finally, it is reported that the Chinese commercial banks with higher levels of capital risk have lower cost, revenue, and profit efficiencies. The importance of capital risk was not reflected from our hypotheses and was not reported in previous Chinese banking studies; this can mainly be attributed to the fact that we focused on different perspectives of bank efficiency compared to the previous studies.

The findings suggest that the higher levels of efficiencies (cost, profit and revenue) of the Chinese commercial banks lead to higher insolvency risk in the Chinese banking industry. This is in line with Tan and Floros (2018) and hypothesis 2. We find that higher instability in the banking industry (higher insolvency risk) leads to a higher level of cost efficiency, revenue efficiency and profit efficiency of the Chinese commercial banks. This result shows the important role played by insolvency risk in bank efficiency from the cost, revenue and profit perspectives, however - as reflected in previous Chinese banking studies - bank efficiency from the technical, pure technical and scale perspectives was not significantly affected by insolvency risk. Finally, we find the influence of competition on insolvency risk is significant and positive, which is in line with hypothesis 1.

$<<$ Table 4-7---about here>> 


\section{Conclusion}

This paper tests the interrelationships between competition, risk and efficiency in the Chinese banking industry over the period 2003-2017. This study significantly contributes to the empirical studies by investigating different types of efficiencies (cost efficiency, profit efficiency and revenue efficiency) under the stochastic frontier analysis, and further tests its interrelationships with different types of risk and competition under a three-stage least square estimator.

The results of this study show that higher competition in the Chinese banking industry leads to higher credit risk, liquidity risk, capital risk and insolvency risk, while higher credit risk, liquidity risk and capital risk lead to an increase in the competition among Chinese commercial banks. In addition, the findings show that the interrelationships between efficiency and competition is significant and negative. We do not find any robust interrelationships between the different types of risk and different types of efficiency. We find that diversification reduces bank credit risk in China, and higher levels of profitability also reduce the level of credit risk. The results suggest that a more highly developed banking sector reduces the level of bank competition in China.

The results of the current paper provide a number of policy implications for bank managers in China, as well as for the banking regulatory authority. From the bank managers' perspective, we recommend that 1) They should further improve the process of credit checking, monitoring and management to reduce the level of credit risk; 2) When engaging in allocating credits to the economic sector, Chinese bank managers should focus more on allocating short-term loans, as the resulted reduction in the level of liquidity risk will improve bank performance; 3) Bank managers should maintain a higher level of capital, which is also for the purpose of risk reduction and performance improvement.

From the banking regulator's perspective, it is recommended that: 1) Relevant rules and regulations should be established to forbid banks to engage in risky activities and restrict them from lending to specific borrowers with high risk levels; 2) The bank regulator should set up high but reasonable capital and liquidity requirements in order to reduce capital and liquidity risk in the banking system; 3) A relevant reward system should be established to attract talented people in the banking industry and also encourage research and innovative activities; the resulted exploration of new business areas will diversify banking activities, improve banking sector development in China, and finally improve bank stability. 


\section{References:}

Abedifar, P., Molyneux, P., and Tarazi, A. (2013) Risk in Islamic Banking, Review of Finance, 17, 2035-2096.

Agoraki, M. K., Delis, M. D., and Pasiouras, F. (2011) Regulations, competition and bank risk-taking in transition countries, Journal of Financial Stability, 7, 38-48.

Aigner, D., Lovell, C.A., and Schmidt, P. (1977) Formulation and estimation of stochastic frontier production function models, Journal of Econometrics, 6, 21-37.

Allen, F., and Gale, D. (2004) Competition and financial stability, Journal of Money, Credit and Banking, 36, 433-480.

Altunbas, Y., Liu, M.H., Molyneux, P., and Seth, R. (2000) Efficiency and risk in Japanese banking, Journal of Banking and Finance, 24, 1605-1628.

Altunbas, Y., Carbo, S., Gardener, E.P.M., and Molyneux, P. (2007) Examining the relationships between capital, risk and efficiency in European Banking, European Financial Management, 13, 4970.

Anginer, D., Demirguc-Kunt, A., and Zhu, M. (2014) How does Bank competition affect systemic stability? Journal of Financial Intermediation, 23, 1-26.

Beck, T., Jonghe, O., and Schepens, G. (2013a) Bank competition and stability: cross-country heterogeneity, Journal of Financial Intermediation, 22, 218-244.

Beck, T., Demirguc-Kunt, A., and Merrouche, O. (2013b) Islamic vs. conventional banking: Business model, efficiency and stability, Journal of Banking and Finance, 37, 433-447.

Berger, A.N., and DeYoung, R. (1997) Problem loans and cost efficiency in commercial banking, Journal of Banking and Finance, 21, 849-870.

Berger, A. N., and Mester, L. J. (1997) Inside the black box: what explains differences in the efficiencies of financial institutions? Journal of Banking and Finance, 21, 895-947. 
Berger, A. N., Klapper, L., and Turk-Ariss, R. (2009) Bank competition and financial stability, Journal of Financial Services Research 35, 849-870.

Boot, A., and Schmeits, A. (2005) The Competitive Challenge in Banking, Working Paper Series, Amsterdam Center for Law and Economics.

Boyd, J. and DeNicolo, G. (2005) The theory of bank risk-talking revisited, Journal of Finance, 60, 13291343.

Carbo-Valverde, S., Rodriguez-Fernandez, F., and Udell, G. F. (2009) Bank Market Power and SME Financing Constraints, Review of Finance, 13, 309-340.

Chan, Y., Greenbaum, S., and Thakor, A. (1986) Information reusability, competition and bank asset quality, Journal of Banking and Finance, 10, 255-276.

Charnes, A., Cooper, W.W., Lewin, A.Y., and Seiford, L.M. (1995) Data Envelopment Analysis: Theory methodology and applications, Kluwer, Boston.

Demsetz, H. (1973) Industry, Structure, Market Rivalry, and Public Policy, Journal of Law and Economics, 16, 1-9.

Evanoff, D., and Ors, E. (2002) Local Market Consolidation and Bank Productive Efficiency, Working Paper Series, FRB of Chicago.

Fernandez de Guevara, J., Maudos, J., and Perez, F. (2005) Market power in European Banking Sectors, Journal of Financial Services Research, 27, 109-137.

Fernandez de Guevara, J., and Maudos, J. (2007) Explanatory factors of market power in banking: An application to the Spanish case, The Manchester School, 75, 275-296.

Fiordelisi, F., Marques-Ibanez, D., and Molyneux, P. (2011a) Efficiency and risk in European banking, Journal of Banking and Finance, 35, 1315-1326.

Fiordelisi, F., Girardone, C., and Radic, C. (2011b) Price competition, efficiency and riskiness in investment banking, Available at SSRN: http://ssrn.com/abstract=1786753. 
Fitzpatrick, T., and McQuinn, K. (2008) Measuring bank profit efficiency, Applied Financial Economics, 18, 1-8.

Fries, S., and Taci, A. (2005) Cost Efficiency of Banks in Transition: Evidence from 289 Banks in 15 Post Communist Countries, Journal of Banking and Finance, 29, 55-81.

Fu, X., Lin, Y., and Molyneux, P. (2014) Bank competition and financial stability in Asia Pacific, Journal of Banking and Finance, 38, 64-77.

Fu, M. (2009) Competition in Chinese commercial banking, Banking and Finance Review, 1, 1-16.

Fungacova, Z., Solanko, L., and Weill, L. (2010) Market power in the Russian banking industry, International Economics, 124,127-145.

Garcia-Herrero, A., Gavila, S., and Santabarbara, D. (2009) What explains the low profitability of Chinese banks? Journal of Banking and Finance, 33, 2080-2092.

Goddard, J., Molyneux, P., and Wilson, J.O.S. (2009) The financial crisis in Europe: evolution, policy responses and lessons for the future, Journal of Financial Regulation and Compliance, 17, 362-380.

Goldberg, L.G., and Rai, A. (1996) The structure-performance relationship for European banking, Journal of Banking and Finance, 20, 745-771.

Hasan, I, and Marton, K. (2003) Development and efficiency of the banking sector in a transitional economy: Hungarian experience, Journal of Banking and Finance, 27, 2249-2271.

Jeitschko, T.D., and Jeung, S.D. (2005) Incentives for risk-taking in banking- A unified approach, Journal of Banking and Finance, 29, 759-777.

Iannotta, G., Nocera, G., and Sironi, A. (2007) Ownership structure, risk and performance in the European banking industry, Journal of Banking and Finance, 31, 2127-2149.

Kasman, A., and Carvallo, O. (2014) Financial stability, competition and efficiency in Latin America and Caribbean banking, Journal of Applied Economics, 17, 301-324. 
Kasman, A., and Yildirim, C. (2006) Cost and profit efficiencies in transition banking: The case of new EU members, Applied Economics, 38, 1079-1090.

Konara, P., Tan, Y., and Johnes, J. (2019) FDI and heterogeneity in bank efficiency: evidence from emerging markets, Asian Review of Accounting, 49, 100-113.

Liang, Q., Xu, P., and Jiraporn, P. (2013) Board characteristics and Chinese bank performance, Journal of Banking and Finance, 37, 2953-2968.

Liu, H., Molyneux, P., and Wilson, J.O.S. (2013) Competition and stability in European banking: a regional analysis, The Manchester School, 81, 176-201.

Liu, H., and Wilson, J.O.S. (2013) Competition and risk in Japanese banking, European Journal of Finance, 19, 1-18.

Liu, H., Molyneux, P., and Nguyen, L.H. (2012) Competition and risk in South East Asian commercial banking, Applied Economics, 44, 3627-3644.

Martinez-Miera, D., and Repullo, R. (2010) Does Competition Reduce the Risk of Bank Failure? Review of Financial Studies, 23, 3638-3664.

Masood, O., and Sergi, B.S. (2011) China's banking system, market structure and competitive conditions, Frontier of Economics in China, 6, 1, 22-35.

Meeusen, W., and Van de Broeck, J. (1977) Efficiency estimation from Cobb-Douglas production functions with composed error, International Economic Review, 18, 435-444.

Molyneux, P., Liu, H., and Jiang, C. (2014) Bank capital, adjustment and ownership: Evidence from China, Discussion Paper Series, Bank of Finland.

Park, K.H. (2013) Testing for competition in the South Korean and Chinese Commercial Banking Markets, Asia-Pacific Journal of Financial Studies, 42, 56-75.

Schaeck, K. and Cihak, M. (2014) Competition, efficiency and stability in Banking, Financial Management, 43, 215-241. 
Seiford, L.M., and Thrall, R.M. (1990) Recent development in DEA: The mathematical programming approach to frontier analysis, Journal of Econometrics, 46, 7-38.

Smith, R. J., and Blundell, R. W. (1986). An exogeneity test for the simultaneous equation tobit model with an application to labour supply, Econometrica, 54, 679-686.

Soedarmono, W., Machrouh, F., and Tarazi, A. (2013) Bank competition, crisis and risk taking: Evidence from emerging markets in Asia, Journal of International Financial Markets, Institutions and Money, 23, 196-221.

Sun, J., Harimaya, K., and Yamori, N. (2013) Regional economic development, strategic investors and efficiency of Chinese city commercial banks, Journal of Banking and Finance, 37, 1602-1611.

Sun, L., and Chang, T. (2011) A comprehensive analysis of the effects of risk measures on bank efficiency: Evidence from Emerging Asian countries, Journal of Banking and Finance, 35, 1727-1735.

Tan, Y., and Floros, C. (2012) Bank profitability and inflation: the case of China, Journal of Economic Studies, 39, 675-696.

Tan, Y., and Floros, C. (2013a) Market power, stability and performance in the Chinese banking industry, Economic Issues, 18, 65-89.

Tan, Y., and Floros, C. (2013b) Risk, capital and efficiency in Chinese banking, Journal of International Financial Markets, Institutions and Money, 26, 378-393.

Tan, Y., and Floros, C. (2014) Risk, profitability and competition: evidence from the Chinese banking, Journal of Developing Areas, 48, 303-319.

Tan, Y. (2014) Performance, Risk and Competition in the Chinese Banking Industry, Chandos Publishing, Oxford.

Tan, Y. (2016) The impacts of risk and competition on bank profitability in China, Journal of International Financial Markets, Institutions and Money, 40, 85-110. 
Tan, Y., and Anchor. J. (2017a) Does competition only impact on insolvency risk? New evidence from the Chinese banking industry, International Journal of Managerial Finance, 13, 332-354.

Tan, Y., and Anchor, J. (2017b) The impact of risk-taking behaviour and competition on technical efficiency: evidence from the Chinese banking industry, Research in International Business and Finance, 41, 90-104.

Tan, Y., Lau, M, C. K., and Gozgor, G. (2020) Competition and Profitability: impacts on stability in Chinese banking, International Journal of the Economics of Business, https://doi.org/10.1080/13571516.2020.1724009

Tan, Y. (2018). The Impacts of Competition and Risk on Profitability in China: Evidence from Boone Indicator and Stability Inefficiency, Annals of Economics and Finance, 19, 523-554.

Tan, Y., and Floros, C. (2018). Risk, competition and efficiency in banking: evidence from China, Global Finance Journal, 35, 223-236.

Yuan, Y. (2006) The state of competition of the Chinese banking industry, Journal of Asia Economics, 17, 519-534.

Zarutskie, R. (2013) Competition, financial innovation and commercial bank loan portfolios, Journal of Financial Intermediation, 22, 373-396. 
Table 1: Definition of the variables used to estimate the Lerner index

\begin{tabular}{|l|l|l|}
\hline Variable & Notation & Measurement \\
\hline Total cost & COST & $\begin{array}{l}\text { Interest expenses plus non- } \\
\text { interest expenses }\end{array}$ \\
\hline Outputs & Y & $\begin{array}{l}\text { Total loans } \\
\text { Securities } \\
\text { Non-interest income }\end{array}$ \\
\hline Input prices & W & $\begin{array}{l}\text { Input price 1: price of fund- } \\
\text { ratio of interest expenses to } \\
\text { total deposits }\end{array}$ \\
& & $\begin{array}{l}\text { Input price 2: price of capital- } \\
\text { ratio of other non-interest } \\
\text { expenses to fixed assets }\end{array}$ \\
\hline Marginal cost & MC & $\begin{array}{l}\text { Estimated using equation 3 and } \\
\text { equation 4 }\end{array}$ \\
\hline
\end{tabular}


Table 2: Summary statistics of inputs and outputs used to estimate the efficiency scores

\begin{tabular}{|c|c|c|c|c|c|}
\hline Variables & Observations & Mean & S.D. & Min & Max \\
\hline \multicolumn{6}{|l|}{ Inputs } \\
\hline $\begin{array}{l}\text { Total cost } \\
\text { (interest } \\
\text { expenses and } \\
\text { non-interest } \\
\text { expenses) }\end{array}$ & 570 & 3.35 & 0.97 & -0.79 & 6.86 \\
\hline Gross revenue & 570 & 216.63 & 689.53 & 0.001 & 5777.95 \\
\hline $\begin{array}{l}\text { Bank } \\
\text { profitability }\end{array}$ & 570 & 0.009 & 0.007 & -0.04 & 0.106 \\
\hline $\begin{array}{l}\text { Price of funds } \\
\text { (the ratio of } \\
\text { interest } \\
\text { expenses over } \\
\text { total deposits) }\end{array}$ & 570 & 1.27 & 0.18 & 0.74 & 1.96 \\
\hline $\begin{array}{l}\text { Price of capital } \\
\text { (the ratio of } \\
\text { non-interest } \\
\text { expenses over } \\
\text { fixed assets) }\end{array}$ & 570 & 1.92 & 0.26 & 0.68 & 2.83 \\
\hline \multicolumn{6}{|l|}{ Outputs } \\
\hline Total loans & 570 & 4.59 & 0.99 & 0.34 & 7.95 \\
\hline Securities & 570 & 4.21 & 1.04 & -0.405 & 7.87 \\
\hline $\begin{array}{l}\text { Non-interest } \\
\text { income }\end{array}$ & 570 & 2.34 & 1.1 & -2.4 & 5.81 \\
\hline
\end{tabular}

NB: All the variables in this table are in natural logarithm and the unit of all the variables is million RMB, the price of funds and the price of capital are in the format of percentage, while the variables involved in the calculation are measured by million RMB. 
Table 3: Descriptive statistics of the variables used in the current study

\begin{tabular}{|c|c|c|c|c|c|}
\hline Variables & Observations & Mean & S.D. & Min & Max \\
\hline Credit risk & 570 & 2.78 & 4.48 & 0 & 41.86 \\
\hline Liquidity risk & 570 & 0.27 & 0.11 & 0.02 & 0.67 \\
\hline Capital risk & 570 & 11.91 & 4.7 & 0.62 & 62.62 \\
\hline Insolvency risk & 570 & 0.33 & 0.21 & 0.025 & 0.789 \\
\hline $\begin{array}{l}\text { Bank } \\
\text { profitability }\end{array}$ & 570 & 0.009 & 0.007 & -0.04 & 0.106 \\
\hline Bank size & 570 & 4.9 & 0.992 & 0.71 & 8.51 \\
\hline $\begin{array}{l}\text { Bank } \\
\text { diversification }\end{array}$ & 570 & 13.98 & 13.31 & -12.94 & 79.4 \\
\hline $\begin{array}{l}\text { Banking sector } \\
\text { development }\end{array}$ & 570 & 2.22 & 0.24 & 1.98 & 2.66 \\
\hline $\begin{array}{l}\text { Stock market } \\
\text { development }\end{array}$ & 570 & 71.2 & 43.49 & 31.9 & 184.1 \\
\hline Inflation & 570 & 2.86 & 1.92 & -0.77 & 5.86 \\
\hline $\begin{array}{ll}\text { GDP } & \text { growth } \\
\text { rate } & \end{array}$ & 570 & 10.19 & 1.87 & 7.7 & 14.2 \\
\hline
\end{tabular}

NB: All the variables in the above table are in the format of percentage, while in order to calculate the percentage all the variables involved in the calculation are measured by million RMB. Inflation and GDP growth rate are statistics taken directly from World Bank. 
Table 4: Three-stage Least Square for the relationships between credit risk, competition and efficiency

\begin{tabular}{|c|c|c|c|c|c|c|c|c|c|}
\hline $\begin{array}{l}\text { Dependent } \\
\text { Variables: }\end{array}$ & $\begin{array}{l}\text { Credit } \\
\text { Risk }\end{array}$ & Lerner index & $\begin{array}{c}\text { Cost } \\
\text { Efficiency }\end{array}$ & $\begin{array}{l}\text { Credit } \\
\text { Risk }\end{array}$ & Lerner index & $\begin{array}{c}\text { Revenue } \\
\text { Efficiency }\end{array}$ & $\begin{array}{l}\text { Credit } \\
\text { Risk }\end{array}$ & Lerner index & $\begin{array}{c}\text { Profit } \\
\text { Efficiency }\end{array}$ \\
\hline Credit Risk & - & $\begin{array}{c}-0.004 * * * \\
(-13.88) \\
\end{array}$ & $\begin{array}{c}0.0005 * * \\
(2.51) \\
\end{array}$ & & $\begin{array}{c}-0.0005 * * * \\
(-15.35) \\
\end{array}$ & $\begin{array}{c}-0.004 * * * \\
(-4.32) \\
\end{array}$ & - & $\begin{array}{c}-0.0004 * * * \\
(-13.81) \\
\end{array}$ & $\begin{array}{c}-0.003 * * * \\
(-3.91) \\
\end{array}$ \\
\hline Competition & $\begin{array}{c}-723.85 * * * \\
(-13.88)\end{array}$ & - & $\begin{array}{l}3.73 * * * \\
(18.30)\end{array}$ & $\begin{array}{c}-721.75 * * * \\
(-15.35) \\
\end{array}$ & - & $\begin{array}{l}2.87 * * \\
(2.53)\end{array}$ & $\begin{array}{c}-668.15 * * * \\
(-13.81)\end{array}$ & - & $\begin{array}{l}7.6 * * * \\
(7.72)\end{array}$ \\
\hline Efficiency & $\begin{array}{c}25.72 * * \\
(2.51)\end{array}$ & $\begin{array}{l}0.12 * * * \\
(18.30)\end{array}$ & - & $\begin{array}{c}8.55 * * * \\
(4.96)\end{array}$ & $\begin{array}{c}0.004 * * \\
(2.53)\end{array}$ & - & $\begin{array}{c}8.13 * * * \\
(3.18)\end{array}$ & $\begin{array}{c}0.01 * * * \\
(7.72)\end{array}$ & - \\
\hline Bank Size & & & $\begin{array}{l}0.0005 \\
(0.62) \\
\end{array}$ & & & $\begin{array}{l}0.005 \\
(1.20) \\
\end{array}$ & & & $\begin{array}{l}0.004 \\
(1.15) \\
\end{array}$ \\
\hline $\begin{array}{c}\text { Bank } \\
\text { Diversification }\end{array}$ & $\begin{array}{l}-0.03^{*} \\
(1.90) \\
\end{array}$ & & & $\begin{array}{l}-0.03^{*} \\
(1.86) \\
\end{array}$ & & & $\begin{array}{c}-0.03 * * \\
(2.01)\end{array}$ & & \\
\hline Bank Profitability & $\begin{array}{c}-51.94 * * \\
(-2.18) \\
\end{array}$ & & & $\begin{array}{c}-43.44^{*} \\
(-1.83) \\
\end{array}$ & & & $\begin{array}{c}-40.59 * \\
(-1.70) \\
\end{array}$ & & \\
\hline $\begin{array}{c}\text { Banking Sector } \\
\text { Development }\end{array}$ & & $\begin{array}{c}0.03 * * * \\
(18.94)\end{array}$ & & & $\begin{array}{c}0.007 * * * \\
(6.90) \\
\end{array}$ & & & $\begin{array}{c}0.007 * * * \\
(7.30)\end{array}$ & \\
\hline $\begin{array}{l}\text { Stock Market } \\
\text { Development }\end{array}$ & & $\begin{array}{c}-0.0001 * * * \\
(15.08) \\
\end{array}$ & & & $\begin{array}{c}5.44 \mathrm{e}-06 \\
(1.23) \\
\end{array}$ & & & $\begin{array}{c}-0.00001^{* *} \\
(-2.13) \\
\end{array}$ & \\
\hline Inflation Rate & & & $\begin{array}{c}-0.00004 \\
(-0.13) \\
\end{array}$ & & & $\begin{array}{l}-0.001 \\
(-0.85) \\
\end{array}$ & & & $\begin{array}{c}-0.01 * * * \\
(-6.16)\end{array}$ \\
\hline $\begin{array}{c}\text { GDP Growth } \\
\text { Rate } \\
\end{array}$ & & $\begin{array}{c}0.005 * * * \\
(18.80) \\
\end{array}$ & & & $\begin{array}{l}0.001 \\
(0.79) \\
\end{array}$ & & & $\begin{array}{c}0.001 * * * \\
(7.63)\end{array}$ & \\
\hline Constant Term & $\begin{array}{c}-36.88 * * \\
(-2.41) \\
\end{array}$ & $\begin{array}{l}-0.19 * * * \\
(-19.71) \\
\end{array}$ & $\begin{array}{c}1.48 * * * \\
(85.38)\end{array}$ & $\begin{array}{c}5.23 \\
(1.17) \\
\end{array}$ & $\begin{array}{c}-0.025 * * * \\
(-7.13)\end{array}$ & $\begin{array}{c}0.99 * * * \\
(10.95)\end{array}$ & $\begin{array}{c}6.91 \\
(1.49) \\
\end{array}$ & $\begin{array}{c}-0.03 * * * \\
(-9.53)\end{array}$ & $\begin{array}{c}1.09 * * * \\
(13.85)\end{array}$ \\
\hline Time Trend & Yes & Yes & Yes & Yes & Yes & Yes & Yes & Yes & Yes \\
\hline Ownership Type & Yes & Yes & Yes & Yes & Yes & Yes & Yes & Yes & Yes \\
\hline R Square & 0.3895 & 0.3786 & 0.3811 & 0.3799 & 0.3773 & 0.3812 & 0.3824 & 0.3831 & 0.3839 \\
\hline Chi-square & $342.30 * * *$ & $859.55 * * *$ & $3686.5 * * *$ & $411.7 * * *$ & $473.14 * * *$ & $158.53 * * *$ & $383.50 * * *$ & $521.28 * * *$ & $437.04 * * *$ \\
\hline
\end{tabular}

NB: The t-statistics are in parentheses. $* * *, * *$, and $*$ represent the statistical significance at $1 \%, 5 \%$, and $10 \%$, respectively. 
Table 5: Three-stage Least Square for the relationships between liquidity risk, competition and efficiency

\begin{tabular}{|c|c|c|c|c|c|c|c|c|c|}
\hline $\begin{array}{l}\text { Dependent } \\
\text { Variables: }\end{array}$ & $\begin{array}{l}\text { Liquidity } \\
\text { Risk }\end{array}$ & Lerner index & $\begin{array}{c}\text { Cost } \\
\text { Efficiency }\end{array}$ & $\begin{array}{l}\text { Liquidity } \\
\text { Risk }\end{array}$ & Lerner index & $\begin{array}{c}\text { Revenue } \\
\text { Efficiency }\end{array}$ & $\begin{array}{l}\text { Liquidity } \\
\text { Risk }\end{array}$ & Lerner index & $\begin{array}{c}\text { Profit } \\
\text { Efficiency }\end{array}$ \\
\hline Liquidity Risk & - & $\begin{array}{c}0.007 * * * \\
(3.94)\end{array}$ & $\begin{array}{c}0.006 * * * \\
(3.76)\end{array}$ & - & $\begin{array}{c}0.008 * * * \\
(4.61)\end{array}$ & $\begin{array}{c}0.16 * * * \\
(4.03)\end{array}$ & - & $\begin{array}{c}0.006^{* * * *} \\
(3.54)\end{array}$ & $\begin{array}{c}0.22 * * * \\
(6.27)\end{array}$ \\
\hline Competition & $\begin{array}{c}3.57 * * * \\
(3.94)\end{array}$ & - & $\begin{array}{l}2.91 * * * \\
(18.35)\end{array}$ & $\begin{array}{l}3.9 * * * \\
(4.61)\end{array}$ & - & $\begin{array}{c}4.23 * * * \\
(5.16)\end{array}$ & $\begin{array}{c}3.01 * * * \\
(3.54)\end{array}$ & - & $\begin{array}{c}5.83 * * * \\
(7.95)\end{array}$ \\
\hline Efficiency & $\begin{array}{c}0.15 * * * \\
(4.76)\end{array}$ & $\begin{array}{l}0.14 * * * \\
(18.35)\end{array}$ & - & $\begin{array}{c}0.16 * * * \\
(4.03)\end{array}$ & $\begin{array}{c}0.01 * * * \\
(5.16)\end{array}$ & - & $\begin{array}{c}0.28 * * * \\
(6.27)\end{array}$ & $\begin{array}{c}0.02 * * * \\
(7.95)\end{array}$ & - \\
\hline Bank Size & & & $\begin{array}{c}-9.15 e-06 \\
(-0.01)\end{array}$ & & & $\begin{array}{l}0.006 \\
(1.64)\end{array}$ & & & $\begin{array}{c}0.006 * * \\
(2.02)\end{array}$ \\
\hline $\begin{array}{c}\text { Bank } \\
\text { Diversification }\end{array}$ & $\begin{array}{c}-0.00002 \\
(-0.06)\end{array}$ & & & $\begin{array}{c}-3.31 e-06 \\
(-0.01)\end{array}$ & & & $\begin{array}{c}-0.00004 \\
(-0.14)\end{array}$ & & \\
\hline $\begin{array}{c}\text { Bank } \\
\text { Profitability }\end{array}$ & $\begin{array}{c}-0.65 \\
(-1.32)\end{array}$ & & & $\begin{array}{l}-0.85^{*} \\
(-1.72)\end{array}$ & & & $\begin{array}{c}-1.09 * * \\
(-2.19)\end{array}$ & & \\
\hline $\begin{array}{c}\text { Banking Sector } \\
\text { Development }\end{array}$ & & $\begin{array}{c}0.034 * * * \\
(18.91) \\
\end{array}$ & & & $\begin{array}{c}0.01 * * * \\
(7.74)\end{array}$ & & & $\begin{array}{c}0.011 * * * \\
(8.31)\end{array}$ & \\
\hline $\begin{array}{l}\text { Stock Market } \\
\text { Development }\end{array}$ & & $\begin{array}{c}-0.0001 * * * \\
(-14.22)\end{array}$ & & & $\begin{array}{c}0.00001 * * \\
(2.11)\end{array}$ & & & $\begin{array}{c}-5.02 \mathrm{e}-06 \\
(-0.87)\end{array}$ & \\
\hline Inflation Rate & & & $\begin{array}{c}-0.0007 * * \\
(-2.06)\end{array}$ & & & $\begin{array}{l}-0.003 \\
(-1.62) \\
\end{array}$ & & & $\begin{array}{c}-0.012 * * * \\
(-8.09) \\
\end{array}$ \\
\hline $\begin{array}{l}\text { GDP Growth } \\
\text { Rate }\end{array}$ & & $\begin{array}{c}0.005 * * * \\
(19.02)\end{array}$ & & & $\begin{array}{l}0.001 \\
(0.94)\end{array}$ & & $\begin{array}{c}0.01 * * * \\
(2.95)\end{array}$ & $\begin{array}{c}0.001 * * * \\
(8.19)\end{array}$ & \\
\hline Constant Term & $\begin{array}{c}-0.67 * * * \\
(-2.25) \\
\end{array}$ & $\begin{array}{c}-0.23 * * * \\
(-20.90) \\
\end{array}$ & $\begin{array}{c}1.49 * * * \\
(85.55)\end{array}$ & $\begin{array}{c}-0.58 * * * \\
(-6.22) \\
\end{array}$ & $\begin{array}{c}-0.05 * * * \\
(-11.37) \\
\end{array}$ & $\begin{array}{c}1.06 * * * \\
(12.23)\end{array}$ & $\begin{array}{c}-0.7 * * * \\
(-7.43)\end{array}$ & $\begin{array}{c}-0.005 * * * \\
(-12.73)\end{array}$ & $\begin{array}{c}1.14 * * * \\
(14.78)\end{array}$ \\
\hline Time Trend & Yes & Yes & Yes & Yes & Yes & Yes & Yes & Yes & Yes \\
\hline Ownership Type & Yes & Yes & Yes & Yes & Yes & Yes & Yes & Yes & Yes \\
\hline $\mathrm{R}$ square & 0.2918 & 0.2833 & 0.2865 & 0.2879 & 0.2911 & 0.2903 & 0.2927 & 0.2919 & 0.2908 \\
\hline Chi-square & $495.85 * * *$ & $693.93 * * *$ & $3821 * * *$ & $520.17 * * *$ & $343.20 * * *$ & $193.33^{* * *}$ & $544.55 * * *$ & $380.88 * * *$ & $516.9 * * *$ \\
\hline
\end{tabular}

NB: The t-statistics are in parentheses. ${ }^{* *},{ }^{* *}$, and $*$ represent the statistical significance at $1 \%, 5 \%$, and $10 \%$, respectively. 
Table 6: Three-stage Least Square for the relationships between capital risk, competition and efficiency

\begin{tabular}{|c|c|c|c|c|c|c|c|c|c|}
\hline $\begin{array}{l}\text { Dependent } \\
\text { Variables: }\end{array}$ & $\begin{array}{l}\text { Capital } \\
\text { Risk }\end{array}$ & Lerner index & $\begin{array}{c}\text { Cost } \\
\text { Efficiency }\end{array}$ & $\begin{array}{c}\text { Capital } \\
\text { Risk }\end{array}$ & Lerner index & $\begin{array}{c}\text { Revenue } \\
\text { Efficiency }\end{array}$ & $\begin{array}{c}\text { Capital } \\
\text { Risk }\end{array}$ & Lerner index & $\begin{array}{c}\text { Profit } \\
\text { Efficiency }\end{array}$ \\
\hline Capital Risk & - & $\begin{array}{c}0.0001 * * * \\
(4.53)\end{array}$ & $\begin{array}{c}0.005 * * * \\
(4.28)\end{array}$ & - & $\begin{array}{c}0.0002 * * * \\
(5.12)\end{array}$ & $\begin{array}{c}0.005 * * * \\
(5.80)\end{array}$ & - & $\begin{array}{c}0.0001 * * * \\
(3.32)\end{array}$ & $\begin{array}{c}0.006^{* * *} \\
(7.46)\end{array}$ \\
\hline Competition & $\begin{array}{c}245.17 * * * \\
(4.51)\end{array}$ & - & $\begin{array}{l}3.49 * * * \\
(18.18)\end{array}$ & $\begin{array}{c}254.22 * * * \\
(5.28)\end{array}$ & - & $\begin{array}{c}3.73 * * * \\
(3.54)\end{array}$ & $\begin{array}{c}167.35 * * * \\
(3.32)\end{array}$ & - & $\begin{array}{l}7.97 * * * \\
(8.74)\end{array}$ \\
\hline Efficiency & $\begin{array}{c}12.96^{* * * *} \\
(3.28)\end{array}$ & $\begin{array}{l}0.13 * * * \\
(18.18)\end{array}$ & - & $\begin{array}{c}11.64 * * * \\
(5.80)\end{array}$ & $\begin{array}{c}0.006 * * * \\
(3.54)\end{array}$ & - & $\begin{array}{c}16.7 * * * \\
(7.46)\end{array}$ & $\begin{array}{c}0.03 * * * \\
(8.74)\end{array}$ & - \\
\hline Bank Size & & & $\begin{array}{c}0.0007 \\
(0.99)\end{array}$ & & & $\begin{array}{l}0.007 * \\
(1.72)\end{array}$ & & & $\begin{array}{l}0.006^{*} \\
(1.68)\end{array}$ \\
\hline $\begin{array}{c}\text { Bank } \\
\text { Diversification }\end{array}$ & $\begin{array}{l}-0.011 \\
(-0.74)\end{array}$ & & & $\begin{array}{c}-0.01 \\
(-0.69)\end{array}$ & & & $\begin{array}{c}-0.01 \\
(-0.93)\end{array}$ & & \\
\hline $\begin{array}{c}\text { Bank } \\
\text { Profitability }\end{array}$ & $\begin{array}{c}-8.87 \\
(-0.38)\end{array}$ & & & $\begin{array}{l}-19.66 \\
(-0.85)\end{array}$ & & & $\begin{array}{l}-28.47 \\
(-1.23)\end{array}$ & & \\
\hline $\begin{array}{c}\text { Banking Sector } \\
\text { Development }\end{array}$ & & $\begin{array}{l}0.03 * * * \\
(20.01)\end{array}$ & & & $\begin{array}{c}0.009 * * * \\
(8.69)\end{array}$ & & & $\begin{array}{c}0.0097 * * * \\
(9.22)\end{array}$ & \\
\hline $\begin{array}{l}\text { Stock Market } \\
\text { Development }\end{array}$ & & $\begin{array}{c}-0.0001 * * * \\
(-14.76)\end{array}$ & & & $\begin{array}{l}6.72 \mathrm{e}-06 \\
(1.43)\end{array}$ & & & $\begin{array}{c}-0.00001^{* *} \\
(-2.03)\end{array}$ & \\
\hline Inflation Rate & & & $\begin{array}{l}-0.0002 \\
(-0.55)\end{array}$ & & & $\begin{array}{l}-0.001 \\
(-0.81)\end{array}$ & & & $\begin{array}{c}-0.01 * * * \\
(-6.73)\end{array}$ \\
\hline $\begin{array}{l}\text { GDP Growth } \\
\text { Rate }\end{array}$ & & $\begin{array}{c}0.005 * * * \\
(18.60)\end{array}$ & & & $\begin{array}{c}0.0008 \\
(0.87)\end{array}$ & & & $\begin{array}{c}0.002 * * * \\
(7.68)\end{array}$ & \\
\hline Constant Term & $\begin{array}{c}0.61 \\
(0.04)\end{array}$ & $\begin{array}{l}-0.21 * * * \\
(-20.36)\end{array}$ & $\begin{array}{l}1.48 * * * \\
(85.98)\end{array}$ & $\begin{array}{c}-4.32 \\
(-0.94)\end{array}$ & $\begin{array}{c}-0.04 * * * \\
(-9.87)\end{array}$ & $\begin{array}{c}0.93 * * * \\
(10.42)\end{array}$ & $\begin{array}{c}-10.87 * * \\
(-2.32)\end{array}$ & $\begin{array}{c}-0.04 * * * \\
(-12.16)\end{array}$ & $\begin{array}{l}1.05 * * * \\
(13.44)\end{array}$ \\
\hline Time Trend & Yes & Yes & Yes & Yes & Yes & Yes & Yes & Yes & Yes \\
\hline $\begin{array}{c}\text { Ownership } \\
\text { Type }\end{array}$ & Yes & Yes & Yes & Yes & Yes & Yes & Yes & Yes & Yes \\
\hline $\mathrm{R}$ square & 0.2913 & 0.2931 & 0.2928 & 0.2921 & 0.2937 & 0.2934 & 0.2917 & 0.2911 & 0.2922 \\
\hline Chi-square & $109.61 * * *$ & $570.72 * * *$ & $3686.7 * * *$ & $151.98 * * *$ & $220.73 * * *$ & $175.52 * * *$ & $167.71 * * *$ & $284.19 * * *$ & $460.88^{* * * *}$ \\
\hline
\end{tabular}

NB: The t-statistics are in parentheses. ${ }^{* *}, * *$, and * represent the statistical significance at $1 \%, 5 \%$, and $10 \%$, respectively. 
Table 7: Three-stage Least Square for the relationships between insolvency risk, competition and efficiency

\begin{tabular}{|c|c|c|c|c|c|c|c|c|c|}
\hline $\begin{array}{l}\text { Dependent } \\
\text { Variables: }\end{array}$ & $\begin{array}{c}\text { Insolvency } \\
\text { Risk }\end{array}$ & Lerner index & $\begin{array}{c}\text { Cost } \\
\text { Efficiency }\end{array}$ & $\begin{array}{c}\text { Insolvency } \\
\text { Risk }\end{array}$ & Lerner index & $\begin{array}{c}\text { Revenue } \\
\text { Efficiency }\end{array}$ & $\begin{array}{c}\text { Insolvency } \\
\text { Risk }\end{array}$ & Lerner index & $\begin{array}{c}\text { Profit } \\
\text { Efficiency }\end{array}$ \\
\hline $\begin{array}{c}\text { Insolvency } \\
\text { Risk }\end{array}$ & - & $\begin{array}{c}-0.005 * * * \\
(-5.56)\end{array}$ & $\begin{array}{c}0.04 * * * \\
(11.41)\end{array}$ & - & $\begin{array}{l}0.001 \\
(0.68)\end{array}$ & $\begin{array}{c}0.05 * * * \\
(3.88)\end{array}$ & - & $\begin{array}{c}0.003 * * * \\
(3.57)\end{array}$ & $\begin{array}{c}0.22 * * * \\
(10.33)\end{array}$ \\
\hline Competition & $\begin{array}{c}-8.84 * * * \\
(-5.56)\end{array}$ & - & $\begin{array}{l}2.71 * * * \\
(19.98)\end{array}$ & $\begin{array}{c}-1.04 \\
(-3.68)\end{array}$ & - & $\begin{array}{c}4.51 * * * \\
(6.28)\end{array}$ & $\begin{array}{l}5.3 * * * \\
(3.57)\end{array}$ & - & $\begin{array}{c}5.66 * * * \\
(8.99)\end{array}$ \\
\hline Efficiency & $\begin{array}{l}4.2 * * * \\
(11.41)\end{array}$ & $\begin{array}{l}0.16 * * * \\
(19.98)\end{array}$ & - & $\begin{array}{c}0.22 * * * \\
(3.81) \\
\end{array}$ & $\begin{array}{c}0.01 * * * \\
(6.28) \\
\end{array}$ & - & $\begin{array}{l}1.18 * * * \\
(12.38)\end{array}$ & $\begin{array}{c}0.02 * * * \\
(8.99)\end{array}$ & - \\
\hline Bank Size & & & $\begin{array}{c}-0.0001 \\
(-0.20)\end{array}$ & & & $\begin{array}{l}0.003 \\
(0.75)\end{array}$ & & & $\begin{array}{l}0.002 \\
(0.90)\end{array}$ \\
\hline $\begin{array}{c}\text { Bank } \\
\text { Diversification }\end{array}$ & $\begin{array}{l}0.001 \\
(1.26) \\
\end{array}$ & & & $\begin{array}{l}0.0006 \\
(1.20)\end{array}$ & & & $\begin{array}{l}0.006 \\
(1.27) \\
\end{array}$ & & \\
\hline $\begin{array}{c}\text { Bank } \\
\text { Profitability }\end{array}$ & $\begin{array}{c}0.15 \\
(0.16) \\
\end{array}$ & & & $\begin{array}{c}0.38 \\
(0.38) \\
\end{array}$ & & & $\begin{array}{l}1.91 * * \\
(1.99)\end{array}$ & & \\
\hline $\begin{array}{c}\text { Banking Sector } \\
\text { Development }\end{array}$ & & $\begin{array}{l}0.04 * * * \\
(23.80) \\
\end{array}$ & & & $\begin{array}{c}0.02 * * * \\
(12.83) \\
\end{array}$ & & & $\begin{array}{c}0.02 * * * \\
(13.60) \\
\end{array}$ & \\
\hline $\begin{array}{l}\text { Stock Market } \\
\text { Development }\end{array}$ & & $\begin{array}{c}-0.0002 * * * \\
(-16.70)\end{array}$ & & & $\begin{array}{c}9.41 \mathrm{e}-06^{*} \\
(1.69)\end{array}$ & & & $\begin{array}{c}-4.52 \mathrm{e}-06 \\
(-0.75)\end{array}$ & \\
\hline Inflation Rate & & & $\begin{array}{l}-0.0002 \\
(-0.64)\end{array}$ & & & $\begin{array}{l}-0.001 \\
(-0.96)\end{array}$ & & & $\begin{array}{c}-0.01 * * * \\
(-9.45)\end{array}$ \\
\hline $\begin{array}{l}\text { GDP Growth } \\
\text { Rate }\end{array}$ & & $\begin{array}{c}0.006^{* * * *} \\
(21.06)\end{array}$ & & & $\begin{array}{l}0.001 \\
(0.41)\end{array}$ & & & $\begin{array}{c}0.002^{* * * *} \\
(9.76)\end{array}$ & \\
\hline Constant Term & $\begin{array}{c}-4.90 * * * \\
(-8.96) \\
\end{array}$ & $\begin{array}{c}-0.25 * * * \\
(-23.19) \\
\end{array}$ & $\begin{array}{l}1.43 * * * \\
(88.56)\end{array}$ & $\begin{array}{c}1.39 * * * \\
(7.76)\end{array}$ & $\begin{array}{c}-0.06 * * * \\
(-14.37) \\
\end{array}$ & $\begin{array}{c}1.05888 \\
(12.90) \\
\end{array}$ & $\begin{array}{l}2.3 * * * \\
(13.13) \\
\end{array}$ & $\begin{array}{c}-0.07 * * * \\
(-15.94) \\
\end{array}$ & $\begin{array}{l}1.29 * * * \\
(17.96)\end{array}$ \\
\hline Time Trend & Yes & Yes & Yes & Yes & Yes & Yes & Yes & Yes & Yes \\
\hline $\begin{array}{c}\text { Ownership } \\
\text { Type }\end{array}$ & Yes & Yes & Yes & Yes & Yes & Yes & Yes & Yes & Yes \\
\hline $\mathrm{R}$ square & 0.2652 & 0.2621 & 0.2592 & 0.2633 & 0.2627 & 0.2596 & 0.2649 & 0.2651 & 0.2618 \\
\hline Chi-square & $405.44^{* * * *}$ & $801.86^{* * *}$ & $4576.3 * * *$ & 269.*** & $388.35 * * *$ & $245.11 * * *$ & $487.5^{* * * *}$ & $436.48 * * *$ & $831.1 * * *$ \\
\hline
\end{tabular}

NB: The t-statistics are in parentheses. $* * *, * *$, and * represent the statistical significance at 1\%, 5\%, and 10\%, respectively. 
Figure 1: Competitive conditions in the Chinese banking industry

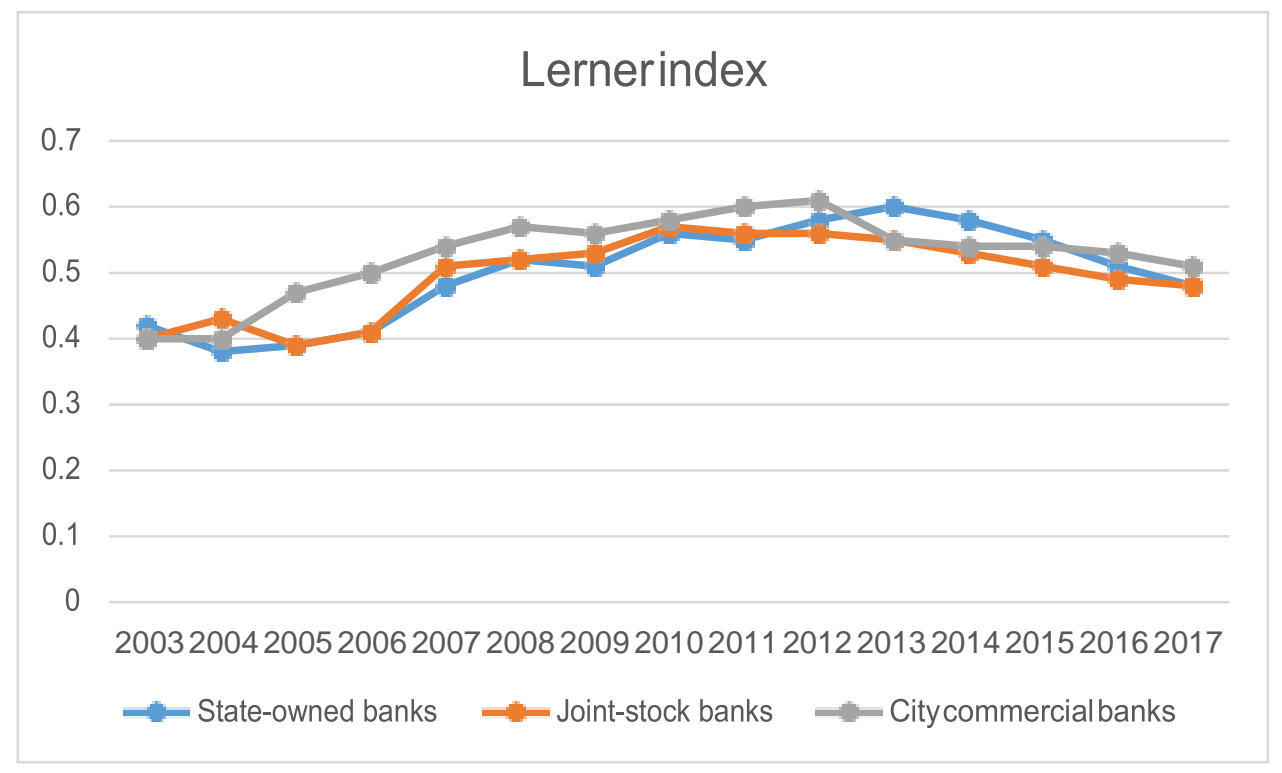

Figure 2: Efficiencies in the Chinese banking industry

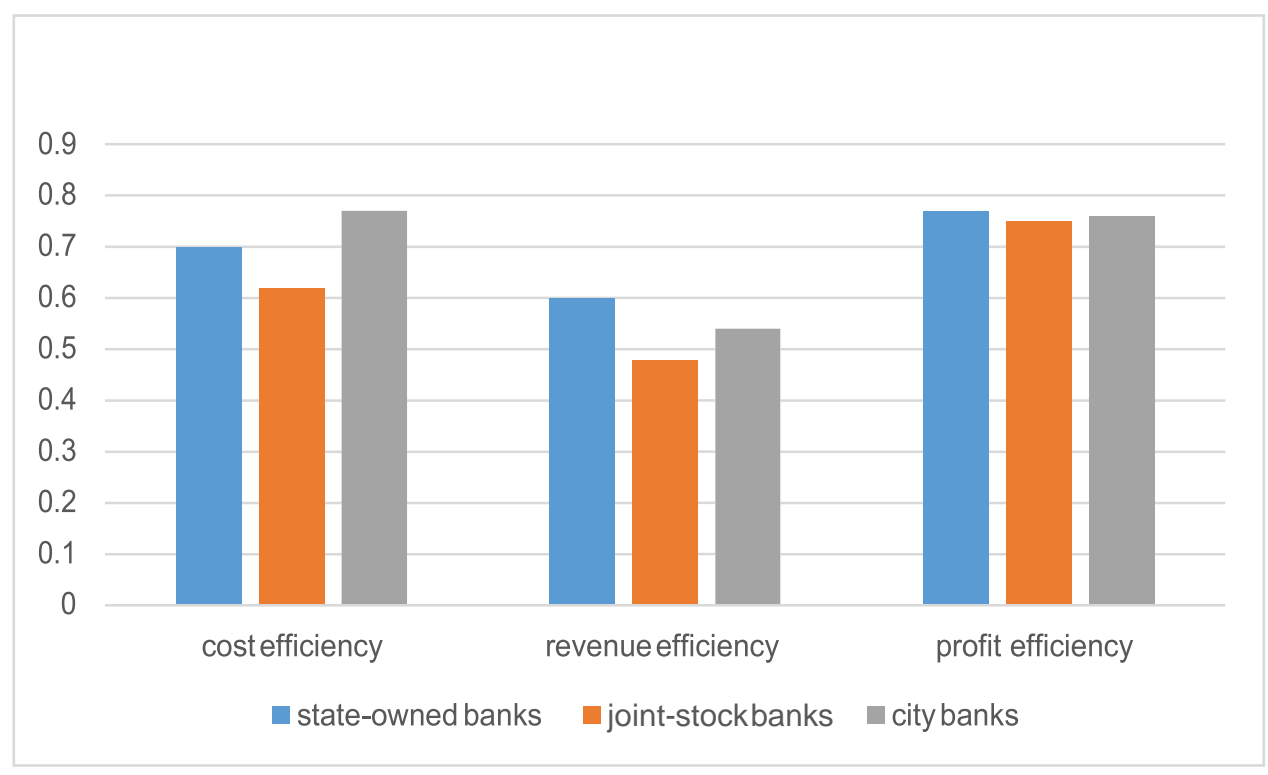


Figure 3: Different types of efficiencies for different ownership types over the examined period
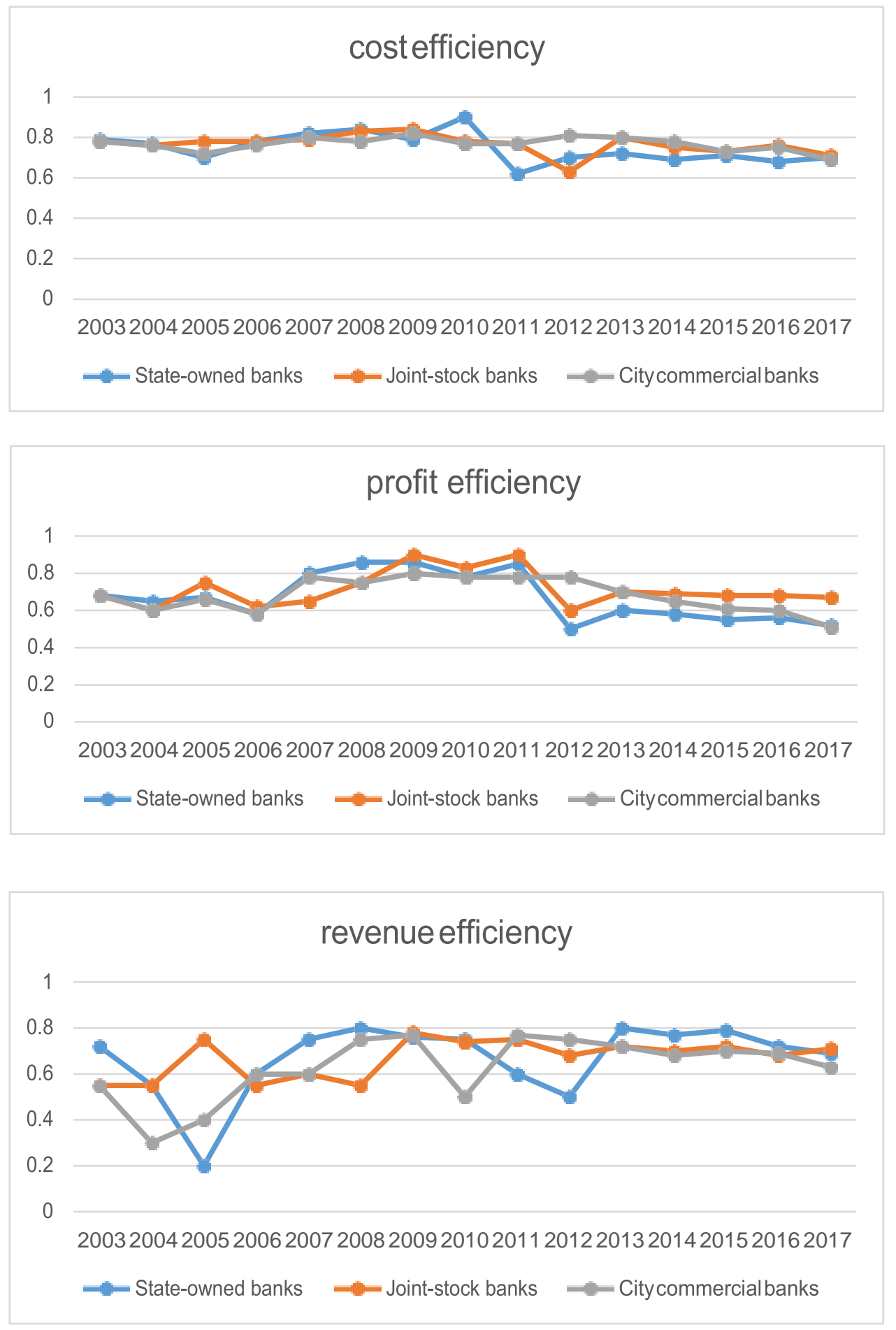